\title{
EXPRESS METHOD FOR SPECIES IDENTIFICATION OF LIVESTOCK PRODUCTS BASED ON MULTIPLEX PCR
}

\author{
Kalendar R., Bektayev R. \\ National Center for Biotechnology \\ 13/5, Korgalzhyn road, Nur-Sultan, 010000, Kazakhstan \\ ruslan.kalendar@mail.ru
}

\begin{abstract}
Food falsification has direct impact on public health, fair-trades and wildlife. A test system for simultaneous detecting DNA of Bos taurus/Ovis aries, Equus cabalus, Sus scrofa, Canis lupus, Mus musculus/Rattus rattus species, and Homo sapiens in livestock products was developed. Species-specific primers sets were designed targeting SINE repeat elements. Screening of target species in commercial sausages reflected its application to detect target species in process foods. The assay was tested to detect at least $0.01 \mathrm{pg}$ DNA under suspected meats in sausages. The high sensitivity and specificity of species identification proposed method was shown. The possibility of using the developed test system for assessing the qualitative composition of various food products was demonstrated.
\end{abstract}

Keywords: multiplex PCR, repeat element, livestock product, food authentication

\section{INTRODUCTION}

Species identification is a major issue due to growing consumer awareness of food composition and the need to verify label claims. Processed meat products are vulnerable to fraudulent labeling because of the economic benefits of selling cheaper meat as a partial or complete substitute for expensive meat. Veterinary and sanitary assessment is necessary to ensure the quality of livestock products and protect public health [1]. The quality criteria include, in particular, the presence of falsifying impurities. The most common way to counterfeit processed meat products is to replace one type with another that is less nutritious in terms of nutrition. The growing demand for transparency in the meat industry and the provision of proper labeling has been a driving force for the development of suitable analytical methodologies for the identification of meat types. Methods based on protein or DNA analysis have been proposed. Protein methods, including electrophoretic, chromatographic. When assessing the origin of livestock products, various analytical methods are used, including mass spectrometry, gas chromatography, enzyme immunoassay, etc. However, these techniques have limitations in the identification of processed products when the destruction of tissue structure and/or degradation of proteins occurs. Unlike proteins, DNA is more stable, and its informativeness as a criterion for species-specificity does not change under the influence of temperature or mechanical factors. As a result, the polymerase chain reaction (PCR) method was proposed to determine the species origin and feedstock composition of livestock products as the least resource-consuming and at the same time the most sensitive and specific [2;3]. At the same time, the problems of optimization of methods and test systems applied to various samples of raw materials and livestock products remain relevant.

It is known that today the genomes of a number of eukaryotes, including the genomes of humans, cows, dogs, sheep and horses, as well as other agricultural species, have been completely sequenced. Most of the studied genomes are represented by various types of repeats, to which retrotransposons make a significant contribution. A specific retrotransposon is repeated in the eukaryotic genome from thousands to millions of times. In addition, such a retrotransposon will 
also be present in other close and distant species. Furthermore, the nucleotide sequence of a particular retrotransposon for different species will also, accordingly, be different. The degree of difference in nucleotide sequences is associated with the genetic relationship of these species. For very close species, the similarity of the sequences of retrotransposons will be greater, for distant species, on the contrary, less. It is obvious that these features of the sequences of retrotransposons, their huge number of copies and representation in all genomes, allow their sequences to be widely used for species identification.

In this work, a real-time multiplex PCR approach is proposed as a simple, fast, sensitive and reliable method for the simultaneous identification of DNA of bovine, sheep, horse, pig, dog, mouse, rat, and human meat detection and quantification. The method was validated to quantify the presence of these DNA in processed commercial sausages products.

\section{Materials and methods}

Sample collection. Specimens of species: Bos taurus, Ovis aries, Equus cabalus, Sus scrofa, Canis lupus, Mus musculus, Rattus rattus, Gallus gallus, Oryctolagus cuniculus were obtained from morphologically confirmed source material. Reference samples were prepared in the laboratory with muscles from a local retail market. Immediately after purchase, both slices of meat were cut and the outside portions rejected. Commercially available livestock product samples of 4 types of products (ground meat, sausage 1-2 and saveloy) were collected from local retailers. All specimens were obtained into small pieces and stored at $-20^{\circ} \mathrm{C}$ to prevent DNA degradation. Human DNA was also used to detect the DNA of hominid species. Samples of commercial processed sausages products were purchased in local supermarkets, including different brands of sausages. For each brand of processed meat products, two samples were acquired in different supermarkets to guarantee that they were from different production batches.

DNA extraction. Briefly, $100 \mathrm{mg}$ of ground and homogenized sample was transferred to a 2 $\mathrm{mL}$ Eppendorf tube followed by the addition of $1 \mathrm{~mL}$ of CTAB extraction buffer CTAB extraction buffer $(2 \%, 2 \mathrm{M} \mathrm{NaCl}, 10 \mathrm{mM} \mathrm{Na} 3$ EDTA, $100 \mathrm{mM}$ HEPES, pH 5.3) with proteinase $\mathrm{K}(30 \mu \mathrm{g} / \mu \mathrm{l})$ (http://primerdigital.com/dna.html). A detailed protocol for DNA isolation was followed as described in Kalendar et al. [4]. The DNA pellets were dissolved with $1 \times$ TE buffer $(1 \mathrm{mM}$ EDTA, $10 \mathrm{mM}$ Tris-HCl, $\mathrm{pH}$ 8.0) with RNase A $(1 \mathrm{ng} / \mathrm{ml})$. The extracted DNA was stored at $4^{\circ}$ C. The DNA quality was checked spectrophotometrically with a Nanodrop apparatus (Thermo Fisher Scientific Inc., Waltham, MA, USA) and also checked by $1 \%$ agarose gel, run at $90 \mathrm{~V}$ for $20 \mathrm{~min}$.

Design of species-specific primers. Species-specific primers were designed by targeting SINE elements. The nucleotide sequences of the SINE elements BOVA2, SINE/tRNA and SINE1/7SL were retrieved form NCBI database (http://www.ncbi.nlm.nih.gov/) and The Genetic Information Research Institute (GIRI) Repbase (https://www.girinst.org/) [5], and were aligned using the multiple sequence alignment EMBL tools (http://www.ebi.ac.uk/Tools/msa/) to select the inter-species hyper-variable and intra-species conserved regions (Table 1). The design of primers and probes was carried out using the FastPCR software (https://primerdigital.com/fastpcr.html) [6;7], through which the selected conservative regions of SINE retrotransposons were analyzed for the design of primers that were optimal for the species identification of animal products. We designed several primer pairs for each of the repeated elements to compare the efficiency and reproducibility of amplification. None of the primer pairs chosen form dimers, and all showed high PCR efficiency. The chosen primers match motifs sufficiently conserved in the retrotransposons to allow amplification of almost all targets in the genome.

Table 1. Repetitive elements for intra-SINE PCR detection assays 


\begin{tabular}{|l|l|l|l|l|l|}
\hline Name & \multicolumn{1}{|c|}{ Order } & \multicolumn{1}{|c|}{ Family } & Genus and species & \multicolumn{1}{c|}{$\begin{array}{c}\text { Repeat element } \\
\text { name }\end{array}$} & $\begin{array}{l}\text { GenBank and } \\
\text { giri accession } \\
\text { no. }\end{array}$ \\
\hline Horse & Perissodactyla & Equidae & Equus caballus & BOVA2 & AF327250 \\
\hline Canine & Carnivora & Canidae & Canis familiaris & SINE2/tRNA & SINEC1A_CF \\
\hline Cow & Artiodactyla & Bovidae & Bos taurus & BOVA2 & AF327250 \\
\hline Sheep & Artiodactyla & Bovidae & Ovis aries & BOVA2 & AF327250 \\
\hline Rat & Rodentia & Muridae & Rattus norvegicus & SINE2/tRNA & Rat_B2_Rat1 \\
\hline Mouse & Rodentia & Muridae & Mus musculus & SINE2/tRNA & Rat_B2_Rat1 \\
\hline Pig & Artiodactyla & Suidae & Sus scrofa & SINE2/tRNA & PRE1_SS \\
\hline Human & Primates & Hominidae & Homo sapiens & SINE1/7SL & AluJ-, AluS- \\
\hline
\end{tabular}

The designed primers were also screened for unique specificity to eliminate cross-species binding with other animal species using the online BLAST local alignment tool in NCBI data base. The designed primers were purchased from Eurofins Genomics (https://www.eurofinsgenomics.eu/). Details of designed primers used in this study are shown in Table 2.

Table 2. Oligonucleotide primers and amplification conditions for $\mathrm{qPCR}$ detection assays

\begin{tabular}{|c|c|c|c|}
\hline Species & Primer ID and sequences (5'-3') & $\begin{array}{l}\text { Primer } \\
\text { location }\end{array}$ & $\begin{array}{c}\text { Amplicon } \\
\text { size (bp) }\end{array}$ \\
\hline Canis sp. & $\begin{array}{l}5100 \text { 5'-GATSCCTGGGTGGCKCAG } \\
5101 \text { 5'-TCGATCCCGGGTCTCCAGGAT } \\
\text { TaqMan 5'-TTAGCGCCTGCCTTTGGCCCAGGGCGT }\end{array}$ & $\begin{array}{l}3 \rightarrow 20 \\
53 \leftarrow 73 \\
25 \rightarrow 51\end{array}$ & 71 \\
\hline Equus sp. & $\begin{array}{l}5188 \text { 5'-CTGTGATGCTGAAAGCTATGCCAC } \\
\text { 5190 5'-TGGCCAGGTCCTTCTTCCTAG } \\
\text { TaqMan 5'-CGCTGAAACCTGTCCACCATGGGTGACC }\end{array}$ & $\begin{array}{l}125 \rightarrow 148 \\
219 \leftarrow 239 \\
170 \leftarrow 197\end{array}$ & 115 \\
\hline $\begin{array}{l}\text { Mus sp. and } \\
\text { Rattus sp. }\end{array}$ & $\begin{array}{l}5109 \text { 5'-GGCTGGAGAGATGGCTCAG } \\
\text { 5110 5'-CAGACACACCAGAAGAGGGCATC } \\
\text { TaqMan 5'-CAGGACCTCTGGAAGAGCAGTCGGTGCT }\end{array}$ & $\begin{array}{l}3 \rightarrow 21 \\
111 \leftarrow 133 \\
30 \leftarrow 57\end{array}$ & 131 \\
\hline Sus sp. & $\begin{array}{l}5112 \text { 5'-TCCCTGCCCTTGCTCAGTGGGT } \\
5113 \text { 5'-ATATGGAGGTTCCCAGGCTAGG } \\
\text { TaqMan 5'-TACACCACAGCTCACGGCAACGCCGGAT }\end{array}$ & $\begin{array}{l}65 \rightarrow 86 \\
194 \leftarrow 215 \\
92 \leftarrow 119\end{array}$ & 151 \\
\hline $\begin{array}{l}\text { Bos sp. and } \\
\text { Ovis sp. }\end{array}$ & $\begin{array}{l}5114 \text { 5'-GAGAAGGCAATGGCACCCCA } \\
\text { 5117 5'-CCCTGGGATTCTCCAGGCAAG } \\
\text { TaqMan 5'-CCATGGGGTCGCTAAGAGTCGGACACGA }\end{array}$ & $\begin{array}{l}2 \rightarrow 21 \\
175 \leftarrow 196 \\
78 \rightarrow 105\end{array}$ & 195 \\
\hline $\begin{array}{l}\text { Homo sapiens } \\
\text { and Homininae }\end{array}$ & $\begin{array}{l}5118 \text { 5'-GTGGCTCACGCCTGTAATCCCA } \\
\text { 5120 5'-CAGGCTGGAGTGCAGTGG } \\
\text { TaqMan 5'-TGCCTCAGCCTCCCGAGTAGCTGGGAC }\end{array}$ & $\begin{array}{l}12 \rightarrow 33 \\
239 \leftarrow 256 \\
163 \leftarrow 189\end{array}$ & 245 \\
\hline $\begin{array}{l}\text { Glycine max } \\
\text { (GmOgre_LTR, } \\
\text { From 17,570 to } \\
19,259 \\
\text { AC236164) }\end{array}$ & $\begin{array}{l}5191 \text { 5'-TCCGTGACACACCGGAAATCA } \\
\text { 5192 5'-CAGGTTGCTTCCTCCAGAAGC } \\
\text { TaqMan 5'-CCAGGCCCACTTGGGCCCTCCAGAAGAT }\end{array}$ & $\begin{array}{l}157 \rightarrow 177 \\
435 \leftarrow 455 \\
234 \rightarrow 261\end{array}$ & 299 \\
\hline
\end{tabular}


Simplex PCR. PCR amplification was accomplished in a $25 \mu \mathrm{l}$ total volume containing $1 \mathrm{U}$ DreamTaq DNA Polymerase (Thermo Fisher Scientific, USA), 1x DreamTaq buffer, $200 \mu \mathrm{M}$ each of dNTP, $1.5 \mathrm{mM} \mathrm{MgCl} 2,0.2 \mu \mathrm{M}$ primers and $5 \mu \mathrm{l}(5 \mathrm{ng} / \mu \mathrm{l})$ of total DNA in $\mathrm{T} 100^{\mathrm{TM}}$ Thermal Cycler (Bio-Rad, USA) and the cycling parameters were initial denaturation at $95{ }^{\circ} \mathrm{C}$ for 2 min following 25 cycles of denaturation at $95^{\circ} \mathrm{C}$ for $15 \mathrm{~s}$, annealing at $60{ }^{\circ} \mathrm{C}$ for $20 \mathrm{~s}$ and elongation at $72{ }^{\circ} \mathrm{C}$ for $10 \mathrm{~s}$ and final elongation at $72{ }^{\circ} \mathrm{C}$ for $2 \mathrm{~min}$.

The amplified products of species-specific simplex PCR products were separated by electrophoresis at $80 \mathrm{~V}$ for $2 \mathrm{~h}$ in $1.5 \%$ agarose gel with 1xTBE buffer. A Thermo Scientific (10010,000 base pairs) GeneRuler DNA Ladder Mix (\#SM0332) was used as a standard DNA ladder. The PCR products were visualized with a ChemiDoc-It2 Imaging System (UVP, LLC, Upland, CA, USA; Analytik Jena AG, Jena, Germany) and a PharosFX Plus Imaging System (Bio-Rad Laboratories Inc., Hercules, CA, USA) with a resolution of $50 \mu \mathrm{m}$, after staining with ethidium bromide.

The sensitivity of the PCRs was performed by adding 10, 5, 1, 0.5, 0.2 and $0.1 \mathrm{pg}$ of DNA template of each species in a common reaction mixture. A sample that did not contain the DNA of the biological objects to be determined was used as a negative control; a standard genetic material (a DNA sample of a known organism) was used as a positive control. $5 \mu 1$ of test sample DNA and $20 \mu 1$ of the corresponding "PCR mixture" were added sequentially into microtubes.

Multiplex PCR. Quantitative real-time multicolor multiplex PCR (qmPCR) reactions were carried out in $25 \mu \mathrm{l}$ using $25 \mathrm{ng}$ of DNA template, 1x DreamTaq PCR buffer (Thermo Fisher Scientific), $0.2 \mathrm{mM}$ dNTPs, $0.2 \mu \mathrm{M}$ each oligonucleotide primer (4 primers set), $0.1 \mu \mathrm{M}$ each oligonucleotide TaqMan probe (4 probes with different color) and 1 unit DreamTaq DNA polymerase. Each sample was subjected to an initial denaturation of 3 minutes at $95^{\circ} \mathrm{C}$, and followed by 30 amplification cycles of denaturation at $95^{\circ} \mathrm{C}$ for $20 \mathrm{~s}$ and 30 secs of anneal/ extension at $60^{\circ} \mathrm{C}$ (detection). Quantitative PCR experiments were performed using an ABI Prism 7000 sequence detection system (Applied Biosystems, Inc.)

Data analysis. Data from duplicate DNA standards were exported from the ABI Prism 7000 SDS software into a Microsoft Excel spreadsheet where the mean value and standard deviation were calculated for each point on the standard curve. Using the Excel trendline option, a line of best fit was plotted with Y error bars equal to 1 standard deviation to form a standard curve. Data from the negative control (no template control- NTC) duplicates and the composite mixed-species DNA test samples (means F1 standard deviation of duplicates) were then plotted on the graph for comparison to the standard curve. Pairwise t tests were performed to determine if the NTC for each assay was statistically different from the minimum value on the standard curve. Data from the multispecies cross-amplification experiments were exported to Excel in a similar manner and the mean and standard deviation of duplicates were calculated. The Excel chart wizard was used to construct bar graphs with Y-error bars equal to 1 standard deviation.

\section{RESULTS AND DISCUSSION}

The effectiveness of quantitative multiplex PCR sets was determined using material isolated from the tissue of meat products of different composition, such as pork, horse meat, beef, chicken, as well as the blood of dogs, cats, rabbits, and mice. A variety of meat products (saveloy, sausages, ground meat, wieners) were purchased from public supermarkets, the blood of animals was taken from the city veterinary clinic. Amplification was performed using several approaches: standard and multiplex PCR. Conventional amplification was used to detect pork content in sausages and other products where it should not be, as indicated by the manufacturer. Performed amplification allows us to make sure that the actions of falsification on the part of the manufacturer's factories are present both to a small and a large extent. Figure 1 presents performed multiplex PCR result, which reveals species-specific DNA fragments in the elements of different 
meat products. Primer specificity of the other species was also examined through multiplex PCR optimized with DNA isolated from other non-target species and meat mixtures. The agarose gel electrophoregram shows different types of meat products of different manufacturers and different compositions, which allows us to see an inaccurate and incomplete correspondence, which is indicated on the manufacturer's label of a certain meat product. Therefore, it is possible to detect the DNA of several animals and analyze several livestock products at the same time by using the multiplex PCR method. The multiplex PCR method makes it possible to determine the species composition of the product, both with and without the stage of DNA extraction and have an ability to find out information about the product in raw state or any state of processing. Counterfeit food products are often found in our stores. This problem with a certain product and manufacturer can be eliminated by using this technique. This method is not limited by food authentication applications, multiplex PCR is used in other different studies.

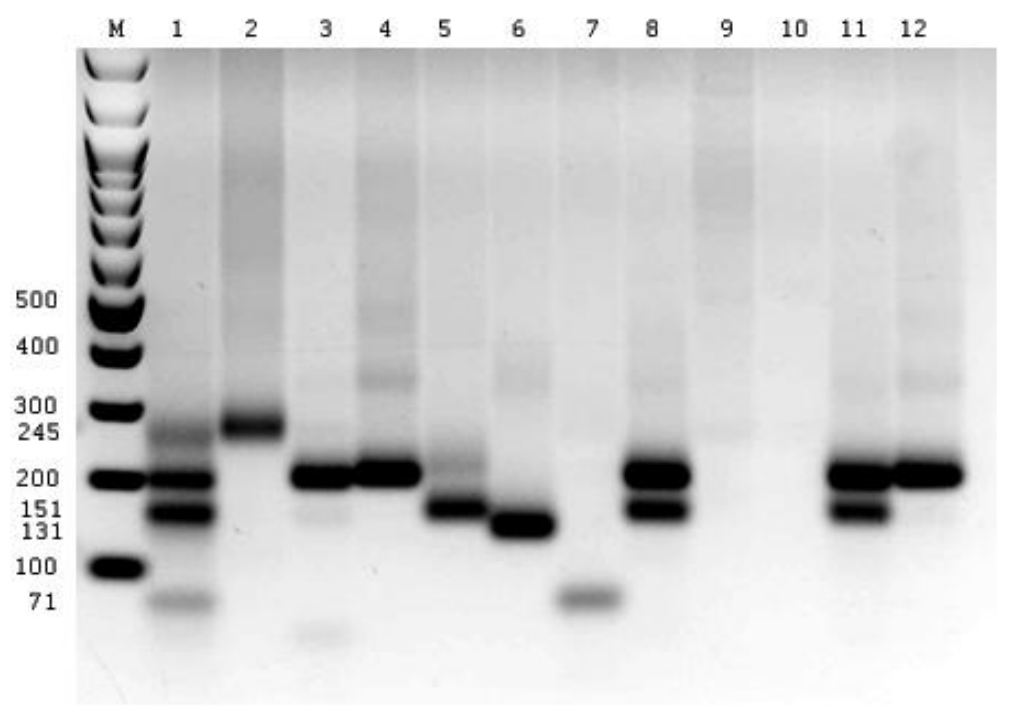

1 - DNA mix (DNA mixture of human, horse, pig and dog); 2 - human blood; 3 - horsemeat; 4 - beef saveloy; 5 - pork sausage; 6 - mouse blood; 7 - dog blood; 8 - beef sausage; 9 - cat blood; 10 - rabbit blood; 11 - halal saveloy; 12 - ground beef. M - Thermo Scientific GeneRuler DNA Ladder Mix (100-10,000 bp).

Fig. 1. Multiplex PCR result for different specimens.

After separation of the amplification products, the interpretation of the results was carried out on the basis of agarose gel visual assessment based on the detection of specific amplified DNA bands on the agarose gel electrophoregram and mobility comparison of PCR fragments of samples and a positive control in the gel (the sizes of PCR fragments are shown in Table 2). Figure 2 shows the results of electrophoresis, which illustrate the composition of animal product assayed samples. 

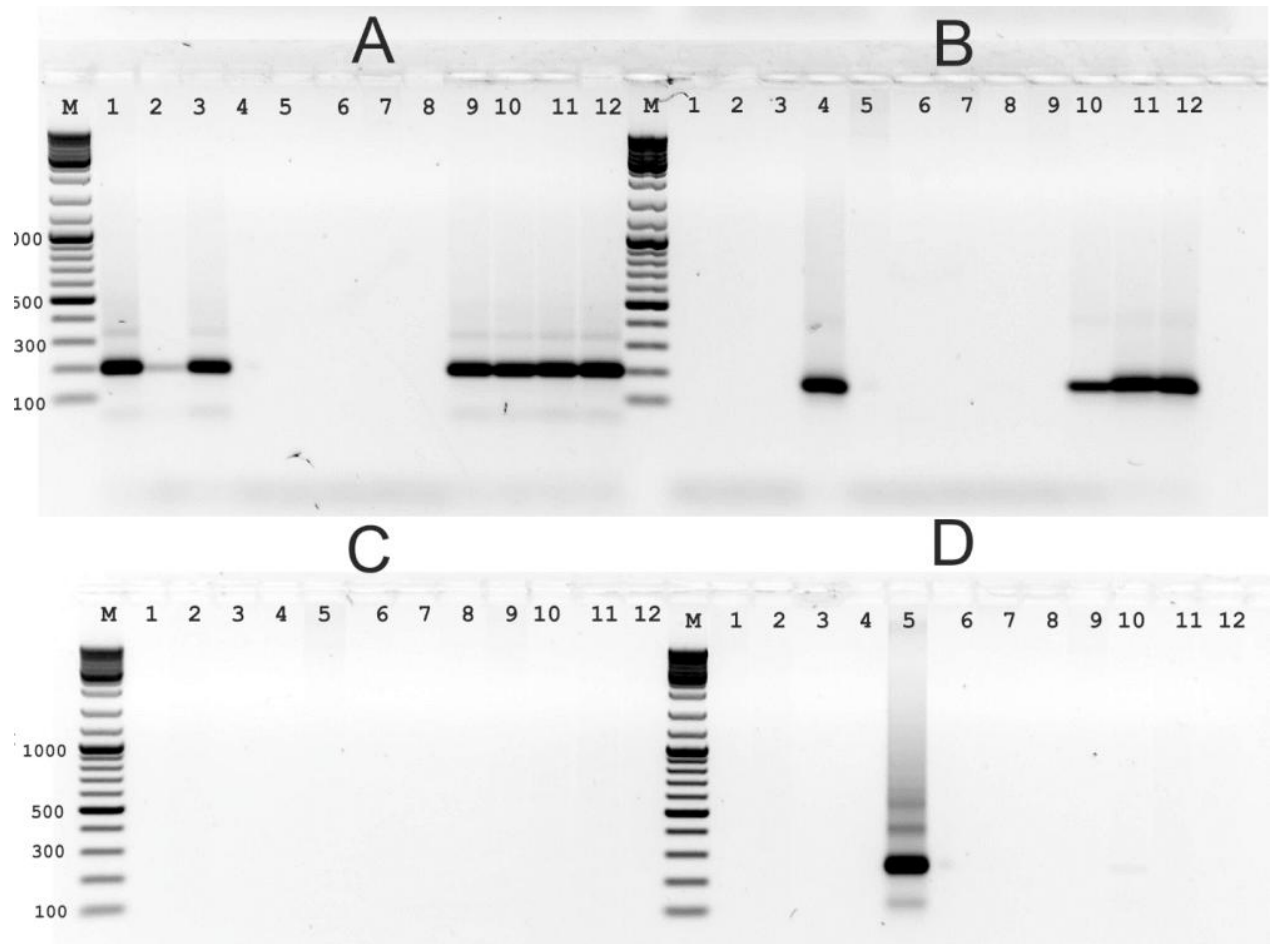

A - Agarose gel electrophoresis of PCR products targeting the SINE elements with primers sets: primers for DNA detection from cattle or sheep- 5114-5117 ; B - primers for DNA detection from pig - 5112-5113; C- primers for DNA detection from rat or mouse - 5109-5110 and D - primers for DNA detection from human - 5118-5120. Lanes in agarose gel contain the following animal product samples: 1 - cattle; 2 - horse; 3 - sheep; 4 - pig; 5 - people;

6 - rabbit; 7 - mouse; 8 - chicken; 9 - ground meat "Muslim" halal; 10 - sausage 1 "April" halal; 11 - sausage 2

"Beef”; 12 - "Moskovskaya" saveloy, M - DNA fragment length marker (GeneRulerTM DNA Ladder Mix).

Fig. 2. Multiplex PCR result for different specimens.

The resulting band pattern leads to the following conclusions. Figure 2A shows the detection of cattle DNA with a developed pair of primers for detecting cattle DNA, but in addition to cow DNA (1), this primer system effectively detects sheep DNA (2), and, less well, horse DNA (3). In the studied food samples (9-12), cow DNA is detected, as efficiently as in the control sample (1). Detection of pig DNA with a pair of primers (2B) reveals the presence of pig DNA in the control sample (4) and in food samples (10-12). In the food sample (11 and 12), the amount of pig DNA is very high, while in the sample (10), the amount of pig DNA is several times lower. During the detection of DNA from rats and mice, samples were analyzed without a control sample (2C). All samples showed no presence of rat or mouse DNA. The detection of human DNA is shown in Figure 2D. DNA is detected only in the control human DNA. The sets of PCR primers developed by us enable to carry out specific and sensitive detection of DNA in raw or processed food samples.

DNA detection for the Bovidae family (cow) from the Artiodactyla order occurs simultaneously with closely related species of this family (sheep), and, weaker, with horse DNA of Perissodactyla order, Equidae family. Thus, this set of PCR primers will effectively detect DNA from all species of the Artiodactyla order, as well as from all species of the Perissodactyla order, but with less sensitivity. Thus, this set of primers has selectivity only at the level of the Artiodactyla and Perissodactyla order, and has no species selectivity. Analogically, the DNA detection of the Muridae family (rats and mice) occurs simultaneously, without species selectivity from this family. DNA detection of a pig from the Artiodactyla order, the Nonruminantia suborder, occurs only at the level of species of one Suidae family - wild boars and pigs. A pair of primers for detecting pig DNA does not detect the presence of DNA from other species from other families of the Nonruminantia suborder of the Artiodactyla order. Human DNA detection is specific to all species of the Homininae subfamily - gorillas, chimpanzees, and humans. 
The obtained results demonstrate the applicability of proposed test system for the analysis of products devoid of morphological and anatomical specific features. Thus, the proposed test system can simultaneously detect the DNA of 7 animal species in livestock product samples - Bos taurus (cattle), Ovis aries (sheep), Equus cabalus (horse), Sus scrofa (pig), Canis lupus (dog), Mus musculus (mouse), Rattus rattus (rat) and Homo sapiens (human).

\section{CONCLUSIONS}

The proposed quantitative real-time multicolor multiplex PCR method proved to be a powerful and simple technique, highly specific and sensitive for DNA identification from of Bos taurus / Ovis aries, Equus cabalus, Sus scrofa, Canis lupus, Mus musculus / Rattus rattus species, and Homo sapiens.

In this study, new specific reaction conditions, methodological approaches and nucleotide sequences of primers were applied as a basis for the development of original test system for the identification of livestock products. As a result, developed test system for the identification of livestock products makes it possible to expand testable DNA categories of types and to determine the DNA of mobile elements in the genomes of 7 animal species simultaneously. The high sensitivity and specificity of the method are due to the fact that the advantages of two most sensitive and specific methods of genome analysis are combined for the identification of animal mobile elements DNA: PCR, which increases the concentration of the desired DNA sequences by a million or more times, and gel electrophoresis, which gives sufficient results for reliable identification of livestock products. The developed real-time quantitative PCR assay allowed the detection and quantification of DNA in the linear dynamic range of 0.001-1\% with high correlation and PCR efficiency.

Using quantitative real-time multicolor multiplex PCR method, it is possible to determine the species origin of both natural and processed products with a significant reduction in time and reagents. All this makes the described test system a useful tool for species identification of livestock products and revealing the facts of their falsification.

Finally, the applicability of the proposed method was demonstrated by the analysis of processed meat products containing mixes of other species as the main ingredient, highlighting its adequacy to estimate adulteration and the need to control processed meat products regarding mislabelling. Hence, it demonstrated that it could be used in inspection programs to enforce labelling regulation in the meat industry. Thus, this method is recommended for use in specialized veterinary, sanitary and epidemiological, livestock and agricultural enterprises.

\section{Acknowledgments}

This work was supported by the Ministry of Education and Science of Kazakhstan (grant № AP05130266).

\section{Ethical compliance}

The ethical permission was obtained from the RSE "National Center for Biotechnology" Ethical Committee and all the animals and meats used in this study were handled following the institutional and national guideline for animal care. 


\title{
REFERENCES
}

1. Aung M.M., Chang Y.S. Traceability in a food supply chain: Safety and quality perspectives. Food Control., 2014,vol. 39, pp. 172-184. doi: 10.1016/j.foodcont.2013.11.007.

2. Soares S., Amaral J.S., Oliveira M.B., Mafra I. A SYBR Green real-time PCR assay to detect and quantify pork meat in processed poultry meat products. Meat Sci., 2013, vol. 94, No. 1, pp. 115-20. doi: 10.1016/j.meatsci.2012.12.012.

3. Ali M.E., Razzak M.A., Hamid S.B., Rahman M.M., Amin M.A., Rashid N.R., Asing. Multiplex PCR assay for the detection of five meat species forbidden in Islamic foods. Food Chem., 2015, vol. 177, pp. 214-24. doi: 10.1016/j.foodchem.2014.12.098.

4. Kalendar R., Boronnikova S., Seppänen M. Isolation and purification of DNA from complicated biological samples. Methods in Molecular Biology, vol. 2222, Besse P.: Springer US, 2021, pp. 1-11. doi: 10.1007/978-1-0716-0997-2_3.

5. Kohany O., Gentles A.J., Hankus L., Jurka J. Annotation, submission and screening of repetitive elements in Repbase: RepbaseSubmitter and Censor. BMC Bioinformatics, 2006, vol. 7, pp. 474. doi: 10.1186/1471-2105-7-474.

6. Kalendar R., Lee D., Schulman A. FastPCR Software for PCR, In Silico PCR, and Oligonucleotide Assembly and Analysis. DNA Cloning and Assembly Methods, vol. 1116, Valla S., Lale R.: Humana Press, 2014, pp. 271-302. doi: 10.1007/978-1-62703-764-8_18.

7. Kalendar R., Khassenov B., Ramanculov E., Samuilova O., Ivanov K.I. FastPCR: An in silico tool for fast primer and probe design and advanced sequence analysis. Genomics, 2017, vol. 109, No. 3-4, pp.312-319. doi: 10.1016/j.ygeno.2017.05.005.

\section{МУЛЬТИТИПЛЕКСТІ ПТР НЕГІЗІНДЕ МАЛ ШАРУАШЫЛЫҒЫ ӨНІМІН ТУРЛІК СӘЙКЕСЕНДІРУДІН ЭКСПРЕСС ӘДІСІ}

\author{
Календарь Р. Н., Бектаев Р. Т.
}

Ұлттық биотехнология ортальвы,

Қоргалжын тас жольы, 13/5, Нұр-Сұлтан, 010000, Қазақстан

ruslan.kalendar@mail.ru

\section{ТУЙІН}

Азық-түлік өнімдерін бұрмалау халықтың денсаулығына, әділ саудаға және қоршаған ортаға тікелей әсер етеді. Мультиплексті ПТР негізінде жануарлар өнімдеріндегі Bos taurus/Ovis aries, Equus cabalus, Sus scrofa, Canis lupus, Mus musculus/Rattus rattus және Homo sapiens түрлері өкілдерінің ДНҚ-сын бір уақытта сәйкестендіруге мүмкіндік беретін тест жүйесі жасалды. Қайталанатын дәйектілікке SINE арналған түр ерекшелікке арналған праймер жиынтығы әзірленді. Өндірілген тағамдардағы коммерциялық қолжетімді шұжық үлгілерінде нысаналы түрлерді скрининг арқылы анықтау, қарастырылған тест жүйесін қолдану мүмкіндігі көрсетілген. Зерттелетін үлгілердің индикация шегі ДНҚ-ны кемінде 0,01 пг мөлшерінде анықтау қабілетіне тексерілді. Ұсынылған әдісті қолдана отырып, мал шаруашылығы өнімдерінің түрлерін сәйкестендірудің жоғары сезімталдығы мен ерекшелігі көрсетілген. Әртүрлі азық-түлік өнімдерінің сапалық құрамын бағалау үшін қарастырылған тест жүйесін қолдану мүмкіндігі көрсетілген.

Негізгі сөздер: мультиплексті ПТР, қайталанатын дәйектілік, мал шаруашылығы өнімдер, тағамның аутентификациясы 


\section{ЭКСПРЕСС МЕТОД ДЛЯ ВИДОВОЙ ИДЕНТИФИКАЦИИ ЖИВОТНОВОДЧЕСКОЙ ПРОДУКЦИИ НА ОСНОВЕ МУЛЬТИПЛЕКСНОЙ ПЦР}

Календарь Р. Н., Бектаев Р. Т.

Национальный центр биотехнологии

Коргалжинское шоссе, 13/5, Нур-Султан, 010000, Казахстан

ruslan.kalendar@mail.ru

АБСТРАКТ

Фальсификация продуктов питания оказывает непосредственное воздействие на общественное здравоохранение, справедливую торговлю и окружающую среду. На основе мультиплексной ПЦР разработана тест-система, позволяющая одновременно идентифицировать ДНК представителей видов Bos taurus/Ovis aries, Equus cabalus, Sus scrofa, Canis lupus, Mus musculus/Rattus rattus и Homo sapiens в животноводческой продукции. Разработаны наборы видоспецифичных праймеров, специфичные для повторяющихся последовательностей SINE. Продемонстрирована возможность использования настоящей тест-системы для идентификации целевых видов в обработанных пищевых продуктах путем их скрининга в коммерчески доступных образцах колбасных изделий. Порог индикации для исследуемых образцов проверен на способность детекции ДНК в количествах не менее 0.01 пг. Показана высокая чувствительность и специфичность видовой идентификации животноводческой продукции с использованием предложенного метода. Продемонстрирована возможность использования настоящей тест-системы для оценки качественного состава различных продуктов питания.

Ключевые слова: мультиплексная ПЦР, повторяющаяся последовательность, животноводческая продукция, аутентификация продуктов питания 
